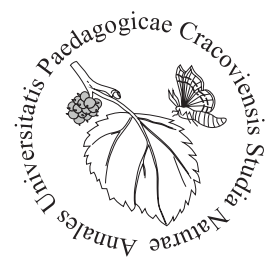

Aleksandra Mazur Cracow Institute of Development and Education, Wielicka 42/105 St., 30-552 Kraków, Poland; aleksandra.mazur.krk@gmail.com

\title{
The role of seed coat in the germination and early stages of growth of bean (Phaseolus vulgaris L.) in the presence of chickweed (Stellaria media (L.) Vill.)
}

Introduction

Human activity is one of the main factors affecting soil, water, air and living organisms pollution. Increasing amounts of chemical compounds used in agriculture, construction and industry contribute to the increase of pollution and degradation of the natural environment. Therefore, more and more often production attempts are madein ecological systems, which are an opportunity for sustainable development and protectionof environmental biodiversity. In ecologic farming, synthetic chemical compounds are replaced by natural substances produced by plants, which is why research into the practical use of allelopathy is desirable.

The term 'allelopathy' comes from the Greek language and is a combination of two words allelon (mutual) and pathos (suffer, harm). In present times, allelopathy was described by Hans Molish (1937), who defined the phenomenon as the interaction of adjacent plants (or microorganisms), of both harmful and beneficial biochemical nature (Gniazdowska et al., 2004). During the first World Allelopathy Congress "Allelopathy - a science for the future" in 1996, deliberations were made to create a definition of the phenomenon described, treating allelopathy as any process involving secondary metabolites produced by plants, microorganisms and fungi that affect the growth and development of biological systems and farming, excluding from these transformations animals (Oleszek, 1996; Wójcik-Wojtkowiak et al., 1998). However, the phenomenon of allelopathy cannot be regarded as a form of direct influence of one plant on another, because metabolites secreted into the environment undergo various transformations. The substance in its original form secreted by the donor plant does not always have to reach the acceptor plant. The level of toxicity of allelopathic compounds is determined by retention, transport and transformation processes (Rice, 1984; Oleszek, 1992). Pos- 
itive allelopathic interactions can have a practical aspect for plant growth. As part of biological competition, they can also perform a protective function against pests, weeds and diseases, increasing plant resistance (Nowiński, 1961).

A bothersome weed of many crops is the chickweed (Stellaria media (L.) Vill.). This species from the family of Caryophyllaceae Juss., is characteristic of weed communities of arable fields and ruderal areas (Matuszkiewicz, 2006). It is an annual or biennial plant, cosmopolitan and nitrophilous. It blooms often all year round and shows germination at low temperatures (van der Vegte, 1978). It grows in segetal areas, landfills, roadside and wastelands. S. media propagates both by seeds and vegetatively. It forms low, dense clusters covered with pale yellow leaves and white flowers (Parus, 2015).

Beans (Phaseolus vulgaris L.) belong to the beans family (Fabaceae Lindl., $=\mathrm{Pa}$ pilionaceae Giseke). It comes from Central and South America. Currently, it is widely grown in more than 200 cultivars on the Old Continent, as well as in Africa and Asia. Its popularity in crops is due to seeds that are rich in protein, contain folic acid, vitamin B6, iron. Bean seed coat is a rich source of biologically active ingredients, among others: amino acids, flavonoids, triterpenes, sugars, steroidal saponins, trace elements, guanidine derivatives, organic acids, vitamins $\mathrm{C}$ and $\mathrm{E}$ (Kuchanowicz et al., 2017).

The interest in seed germination biotests increases every year, which are easy to observation, easy to perform and does not require large financial outlays. In germination biotests, it is important to determine what concentrations of chemicals adversely affect seed germination, plant growth and development. The aim of the study was to investigate the role of seed coat in the germination process and in the early stages of growth of bean seeds (P. vulgaris) in the presence of aqueous extracts from dry shoots of chickweed (S. media). The influence of chickweed extracts on the values of germination index of bean seed with seed coat and seed without it was determined (1), the growth inhibition rate of seedlings was determined (2), the values of fresh and dry matter and the percentage of water content in 7 days seedlings of $P$. vulgaris, grown from seeds with seed coats, as well as without them (3).

\section{Material and methods}

\section{Plant material}

Bean seeds (Phaseolus vulgaris) from the horticultural company POLAN (Kraków, Poland) were used for the experiments. Herbaceous parts of chickweed (Stellaria media) in form of fresh shoots were harvested in southern Poland near Kraków and dried in laboratory conditions. Then they were stored in the dark, so as to avoid microbiological destruction of allelopathic compounds contained in them. 


\section{Extracts preparation}

Aqueous extracts from S. media dry shoots were prepared in three percentage concentrations: 5, 10 and 15\%. Grinded in a grinder (Braun 4045, Germany) shoots of chickweed depending on the concentration were flooded with the appropriate amount of distilled water $(5 \%$ extract $=5 \mathrm{~g}$ dry material $+95 \mathrm{ml}$ cold boiled water, $10 \%$ extract $=10 \mathrm{~g}$ dry material $+90 \mathrm{ml}$ cold boiled water, $15 \%$ extract $=15 \mathrm{~g}$ dry material $+85 \mathrm{ml}$ cold boiled water). The extracts prepared in this way were left for 24 hours in the dark at a temperature of about $25^{\circ} \mathrm{C}$ to extract the chemical compounds contained in them. After one day, extracts from chickweed dry shoots were strained through a double layer of gauze and stored in the refrigerator for the duration of the experiment.

\section{Seeds germination}

Bean seeds, counted 10 for each Petri dishes, were rinsed under running water for 30 minutes, and then 3 times with distilled water and divided into two groups. The first experimental group were beans with seed coats, and the second were seeds without them. In order to easily remove the coat from the seeds, some of them were left for 2-3 hours in distilled water until the coat clearly wrinkled, and then it was removed with a knife so as not to damage the inside of the seed. The seeds of $P$. vulgaris prepared in this way, both with seed coats and without them, were lined with tweezers on Petri dishes, $9 \mathrm{~cm}$ in diameter, with a triple layer of filter paper moistened with $5 \mathrm{ml}$ of appropriate aqueous extract from S. media shoots, at concentrations of 5, 10 and 15\%. The control group consisted of bean seeds, both those with seed coats and seeds without them, put on Petri dishes with filter paper moistened with $5 \mathrm{ml}$ of distilled water. For the duration of the experiment, all seed on Petri dishes were placed in the dark at room temperature. Every $24 \mathrm{~h}$ for 7 days the number of germinated seeds was checked. Germinated seeds were those which germinal root was half the size of the seed.

\section{Germination indexes}

After 7 days of the experiment, the effect of aqueous extracts from S. media dry shoots on the germination indexes of $P$. vulgaris seeds with and without coats were assessed. These formulas of germination indexes are in table 1 .

\section{Biometric analysis}

The length of whole $P$. vulgaris seedlings was measured with a ruler with an accuracy of $1 \mathrm{~mm}$. The impact of $S$. media dry shoots extracts on bean seedling growth on length was determined according to the formula proposed by Islam and Kato-Noguchi (2012): IP = (1 - (LE/LC) $\times 100$; where: IP - growth inhibition index [\%]; LE - seedlings length $(\mathrm{mm})$ treated with emitter data; LC - seedlings length $(\mathrm{mm})$ from the control. 
Tab. 1. Germination index formulas

\begin{tabular}{llc}
\hline Germination index & \multicolumn{1}{c}{ Formula } & \multicolumn{1}{c}{ Author } \\
\hline $\begin{array}{l}\text { GP } \\
\text { (Germination percentage) })\end{array}$ & $\begin{array}{l}\text { GP }=[\text { Number of germinated seeds at everyday/ } \\
\text { Total number of seeds sets for bioassay }] \times 100\end{array}$ & Global method \\
SE & $\begin{array}{l}\text { SE }=\text { (Number of germinated seeds at the start- } \\
\text { ing day of germination/Number of germinated } \\
\text { seeds at the final days of measurement }) \times 100\end{array}$ & Islam et al. (2009) \\
SVI emergence) & SVI $=($ Seedling length $(\mathrm{mm}) \times$ Germination & \\
(Seedling vigour index $)$ & percent $) / 100$ & \\
\hline
\end{tabular}

Fresh and dry mass, water content

The fresh mass of 7-day-old bean seedlings with and without seed coat was determined on the laboratory scale (Ohaus Adventurer Pro, USA). To obtain a dry mass, the plant material was dried for 48 hours at $105^{\circ} \mathrm{C}$ in an dryer (WAMED SUP 100, Poland) and then weighed. On the basis of the mass values obtained, the percentage water content was determined according to the formula: $100-[($ dry mass $\times 100)$ / fresh mass].

\section{Statistical analysis}

The results were developed in Microsoft Excel based on data collected from observations carried out during the experiment. Additionally, statistical analysis was performed using the one-way ANOVA / MANOVA analysis of variance test. Duncan's test at $\mathrm{p} \leq 0.05$ was used to assess the significance of differences between the means \pm SD tested. The data was analysed in StatSoft, Inc. (2018). STATISTICA (data analysis software system), version 13.1. www.statsoft.com.

Results

\section{Germination indexes}

Germination capacity of seeds Phaseolus vulgaris, with seed coat and without it, in the presence of aqueous extracts of dry shoots of Stellaria media with different concentrations of 5, 10,15\% and control conditions was varied (Fig. 1-2).

Among seeds with seed coat, no seeds germinated on the first day of the experiment. On the third day, the highest percentage of germinated seeds was observed on the $10 \%$ extract, where the germination value was $40 \%$. Seeds watered with a $5 \%$ extract and those from the control sample reached value of $30 \%$, while no seeds germinated in the presence of $15 \%$ extract. On the seventh day, the percentage of germinated seeds increased in three cases, reaching the highest value of $80 \%$ for seeds 


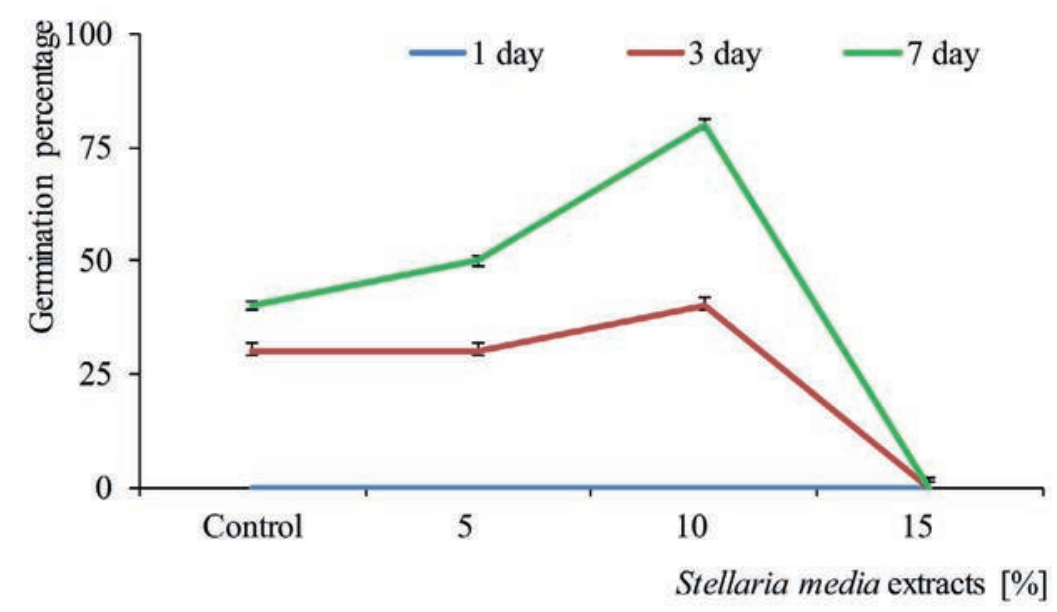

Fig. 1. Percent of germinated seeds Phaseolus vulgaris L. grown from seed with coat in the presence of aqueous extracts from the dry shoots of Stellaria media (L.) Vill. at various concentrations of 5, 10 and $15 \%$ and control conditions (distilled water)

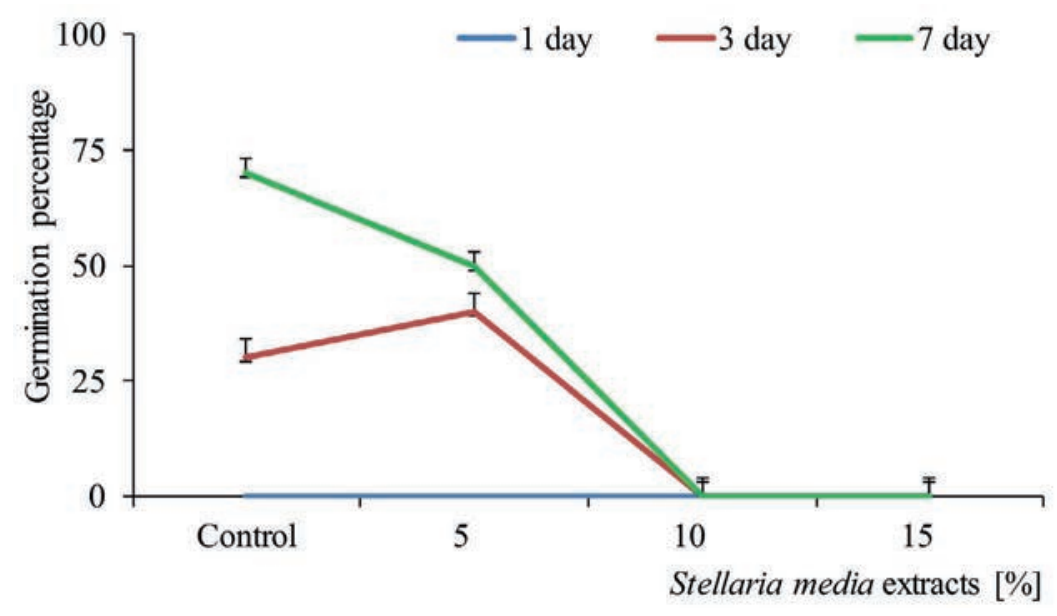

Fig. 2. Percent of germinated seeds Phaseolus vulgaris L. grown from seed without coat in the presence of aqueous extracts from the dry shoots of Stellaria media (L.) Vill. at various concentrations of 5, 10 and $15 \%$ and control conditions (distilled water)

germinating in the presence of $10 \%$ extract, $50 \%$ for seeds watered with $5 \%$ extracts, and $40 \%$ for the control sample. Only on the $15 \%$ extract of chickweed, no germinated seeds were observed (Fig. 1). 
For P. vulgaris seeds without coat, germination began only on the third day of observation. The largest number of newly germinated bean seeds was on the seventh day of experiment for seeds from the control sample. A slightly smaller number of germinated seed, compared to the control, was observed on dishes with 5\% chickweed extract. In the other two cases, in the presence of 10 and $15 \%$ extracts, no bean germination was noted until the end of the experiment (Fig. 2).

In the case of seed emergence (SE), the highest, though uneven, results were obtained for bean seeds watered with $5 \%$ aqueous extract from S. media shoots (at $60 \%$ for seeds with coat and $80 \%$ for seeds without it). Similar values of SE were achieved by bean seeds with coat watered with distilled water (control test). Lower values of the discussed coefficient apply to seeds of $P$. vulgaris with coat, germinating in the presence of $10 \%$ extracts and seeds without seed coat from the control sample. Compared to the control conditions, the extract of $15 \%$ from chickweed shoots, regardless of the presence or absence of seed coat, inhibited the germination of bean seeds in 100\% (Fig. 3-4).

Seed vigour index (SVI) has a similar values, both for seeds germinating with and without seed coat (Fig. 5-6). In both cases, both on the $3^{\text {rd }}$ and the last $7^{\text {th }}$ day, it was observed that the higher the concentration of the aqueous extract from S. media, the higher the seedling viability (up to $10 \%$ for seeds with coat and to $5 \%$ without coat).

In the studied sample of seed with coat, the highest value of the SVI index was recorded for seedlings $P$. vulgaris watered with $10 \%$ extracts, in relation to the control. For seeds without coat, the highest value of this parameter was observed in the case of the control sample. At $15 \%$ of the extract concentration, the bean SVI index, for both seed with and without coat, had 0 value.

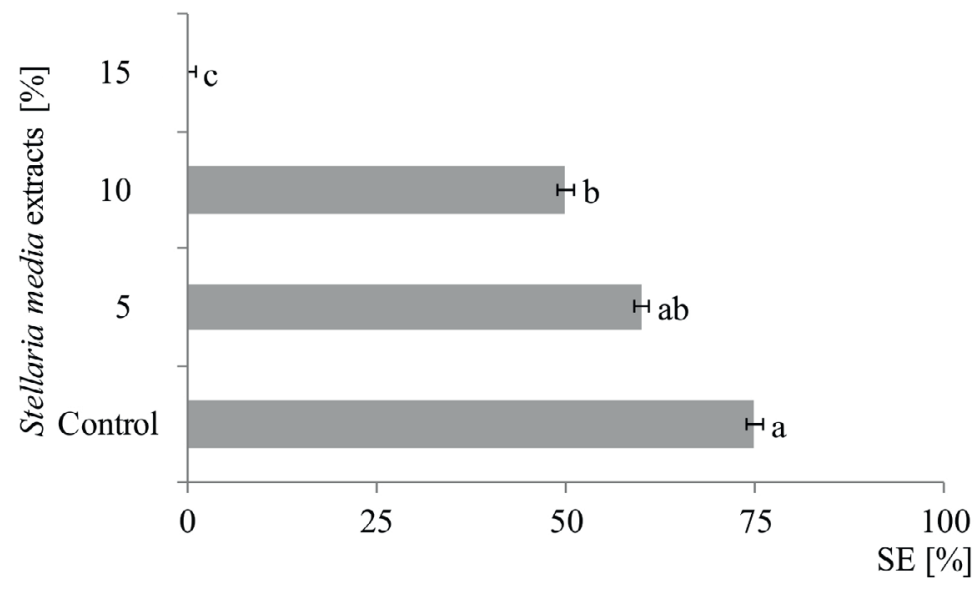

Fig. 3. Seed emergence (SE) of seeds Phaseolus vulgaris L. grown from seed with coat in the presence of aqueous extracts from dry shoots of Stellaria media (L.) Vill. at various concentrations of 5, 10, 15\% and control conditions (distilled water); mean values \pm SD marked with letters a, b, c differ significantly according to Duncan's test $\mathrm{p} \leq 0.05$ 


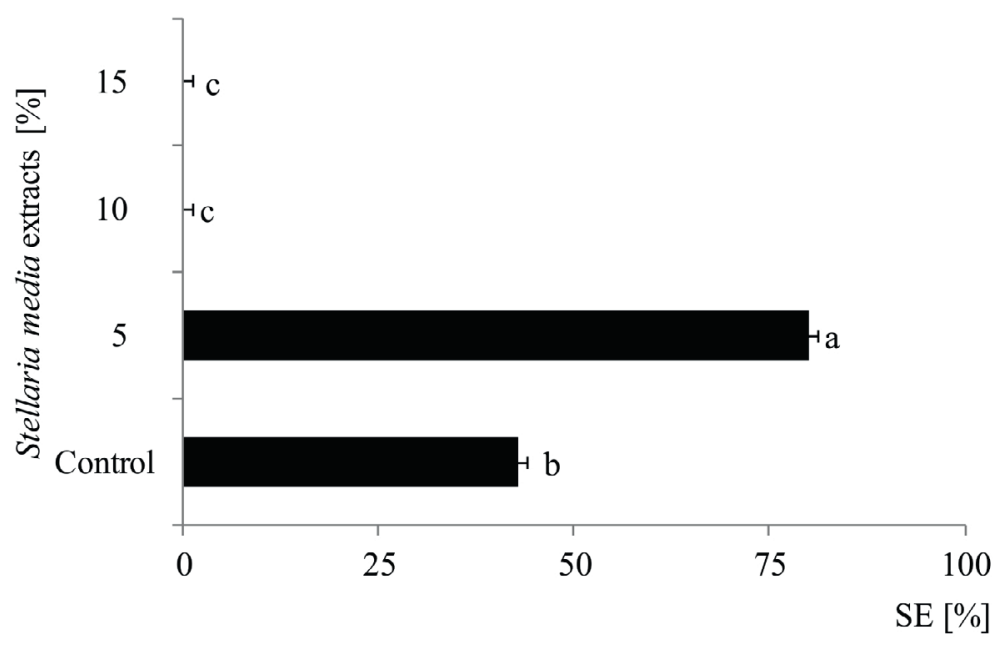

Fig. 4. Seed emergence (SE) of seeds Phaseolus vulgaris L. grown from seed without coat in the presence of aqueous extracts from dry shoots of Stellaria media (L.) Vill. at various concentrations of 5, 10, 15\% and control conditions (distilled water); mean values \pm SD marked with letters $a, b, c$ differ significantly according to Duncan's test $\mathrm{p} \leq 0.05$

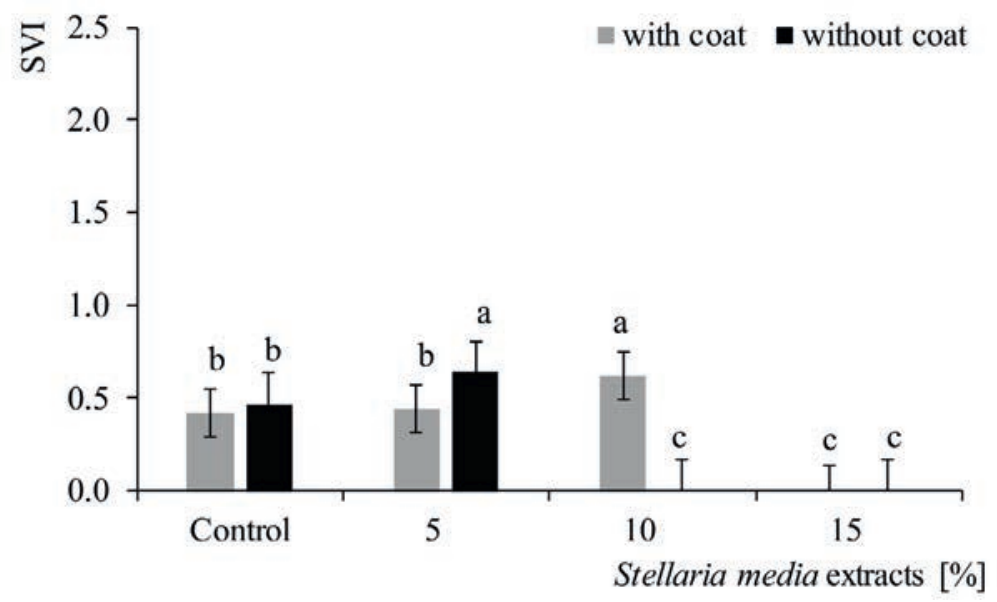

Fig. 5. Seed vigour index (SVI) of Phaseolus vulgaris L. grown from seeds with and without coat, on the $3^{\text {th }}$ germination day, in the presence of aqueous extracts from dry shoots of Stellaria media (L.) Vill. at various concentrations of 5,10 and $15 \%$ and control conditions (distilled water); mean values \pm SD marked with letters a, b, c differ significantly according to Duncan's test $\mathrm{p} \leq 0.05$

\section{Biometric analysis}

Biometric analysis of $P$. vulgaris seedlings germinated from seed with coat showed that both extracts at 5 and $10 \%$ concentrations stimulated the growth of them, compared to control. In the case of bean seeds germinating without coat, the growth inhibition 


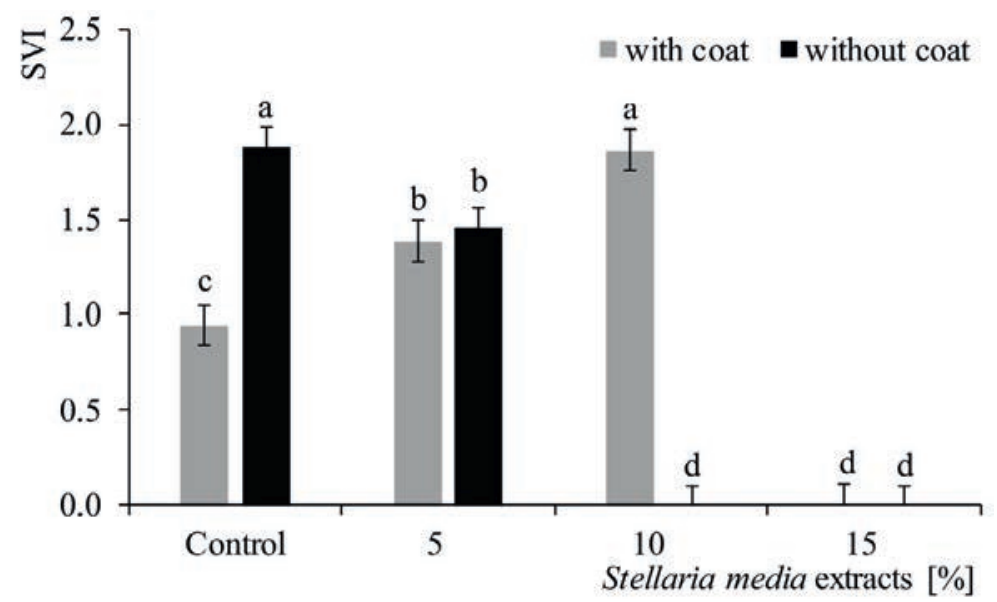

Fig. 6. Seed vigour index (SVI) of Phaseolus vulgaris L. grown from seeds with and without coat, on the $7^{\text {th }}$ germination day, in the presence of aqueous extracts from dry shoots of Stellaria media (L.) Vill. at various concentrations of 5, 10 and $15 \%$ and control conditions (distilled water); mean values \pm SD marked with letters $\mathrm{a}, \mathrm{b}, \mathrm{c}$ differ significantly according to Duncan's test $\mathrm{p} \leq 0.05$

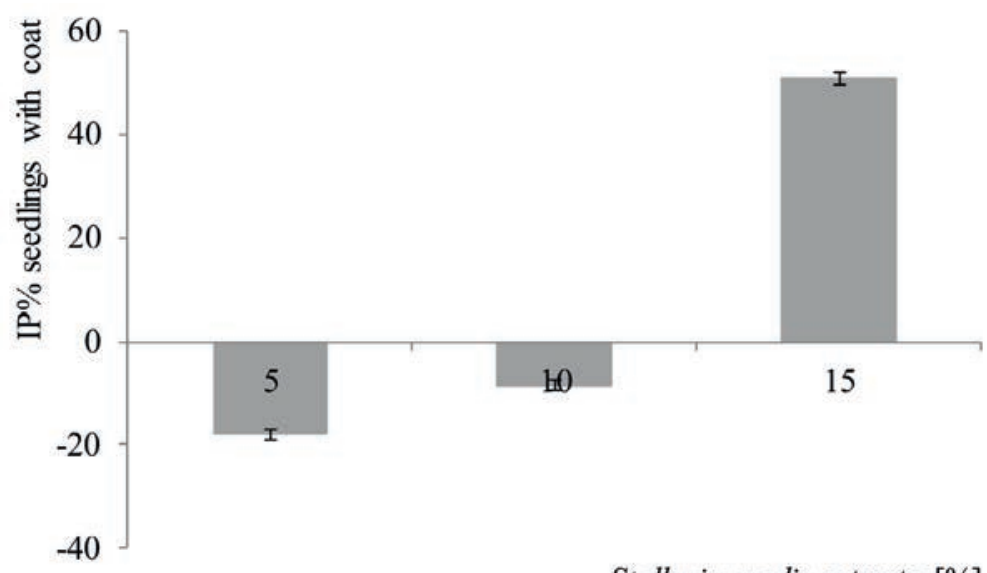

Stellaria media extracts [\%]

Fig. 7. Inhibition percentage index of growth (IP) (expressed as a percentage of control value) of Phaseolus vulgaris L. germinated seed with coat in the presence of aqueous extracts from Stellaria media (L.) Vill. at various concentrations of 5, 10 and $15 \%$ and control (distilled water); a negative (-) value on the $Y$ axis indicates growth, and a positive $(+)$ value indicates growth inhibition

had already occurred in the presence of $10 \%$ extracts. Regardless of the presence or absence of seed coat, clear inhibition of the growth in length of $P$. vulgaris seedlings was caused by extracts of $15 \%$ concentration from S. media, compared to seedlings grown in control (Fig. 7-8). 


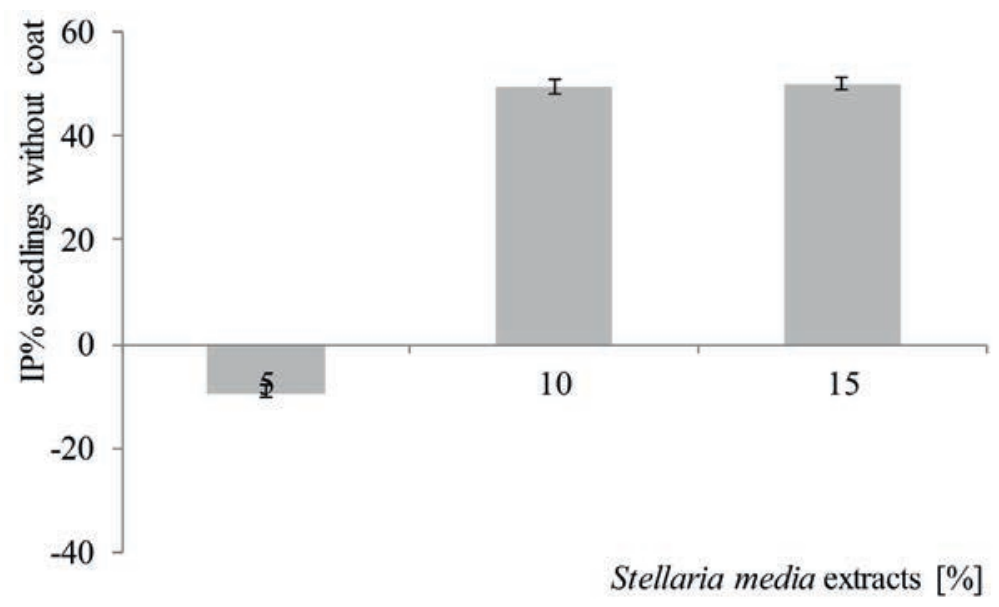

Fig. 8. Inhibition percentage index of growth (IP) (expressed as a percentage of control value) of Phaseolus vulgaris L. germinated seed without coat in the presence of aqueous extracts from Stellaria media (L.) Vill. at various concentrations of 5, 10 and $15 \%$ and control (distilled water); a negative (-) value on the Y axis indicates growth, and a positive $(+)$ value indicates growth inhibition

\section{Fresh and dry mass, water content}

Analysing the values of fresh mass of bean seedlings watered with aqueous extracts from $S$. media shoots, significant differences were found compared to the control (Tab. 3). The highest increase in fresh mass was observed in P. vulgaris watered with $5 \%$ extracts (for seeds with coat) and for seedlings watered with 5 and $10 \%$ extracts (for seeds without coat).

In the case of dry mass, the only significant statistical differences in the values of this parameter noticed for bean seedlings grown with seed coat on $5 \%$ extracts, compared to the dry mass of seedlings watered with distilled water (Tab. 3). In other cases, regardless of the type of seeds analysed, dry mass values changed slightly.

Tab. 2. Changes in the length of Phaseolus vulgaris L. seedlings $[\mathrm{cm}]$ grown from seeds with seed coat (A) and without seed coat - (B) in the presence of aqueous extracts from dry shoots of Stellaria media (L.) Vill. at different concentrations of 5, 10 and $15 \%$ and control (distilled water), marked on different days of the experiment (days 1, 3 and 7)

\begin{tabular}{lcccccccc}
\hline & \multicolumn{8}{c}{ Stellaria media extract [\%] } \\
\cline { 2 - 10 } Day & \multicolumn{2}{c}{ Control } & \multicolumn{2}{c}{5} & \multicolumn{2}{c}{10} & \multicolumn{3}{c}{15} \\
\cline { 2 - 10 } & $\mathrm{A}$ & $\mathrm{B}$ & $\mathrm{A}$ & $\mathrm{B}$ & $\mathrm{A}$ & $\mathrm{B}$ & $\mathrm{A}$ & $\mathrm{B}$ \\
\hline 1 & $1.25 \mathrm{~b}$ & $1.30 \mathrm{~b}$ & $1.45 \mathrm{~b}$ & $1.35 \mathrm{~b}$ & $1.35 \mathrm{~b}$ & $1.25 \mathrm{~b}$ & $1.15 \mathrm{~b}$ & $1.25 \mathrm{~b}$ \\
3 & $1.40 \mathrm{~b}$ & $1.55 \mathrm{~b}$ & $1.45 \mathrm{~b}$ & $1.60 \mathrm{~b}$ & $1.55 \mathrm{~b}$ & $1.25 \mathrm{~b}$ & $1.15 \mathrm{~b}$ & $1.25 \mathrm{~b}$ \\
7 & $2.45 \mathrm{a}$ & $2.55 \mathrm{a}$ & $2.65 \mathrm{a}$ & $2.25 \mathrm{a}$ & $2.00 \mathrm{ab}$ & $1.25 \mathrm{~b}$ & $1.15 \mathrm{~b}$ & $1.25 \mathrm{~b}$ \\
\hline
\end{tabular}

mean values \pm SD marked with letters $a, b, c$ differ significantly according to Duncan's test $p \leq 0.05$ 
The percentage of water content in the control samples was $35.37 \%$ for bean seed with coat and $44.56 \%$ for seed without it. Both in the first and second analysed samples, the value of the parameter increased significantly in seedlings watered with $5 \%$ extracts of chickweed extracts, compared to the control sample (Tab. 3). However, as the concentration of allelopathic compounds increased in aqueous extracts from $S$. media, a decrease in the water content of bean seedlings was observed in each of the studied samples.

Tab. 3. Fresh and dry mass values and percentage of water content in Phaseolus vulgaris L. seedlings grown from seed with seed coat - (A) and without seed coat - (B) in the presence of aqueous extracts from shoots of Stellaria media (L.) Vill., with different concentrations of 5, 10 and $15 \%$ and control (distilled water)

\begin{tabular}{|c|c|c|c|c|c|c|c|c|}
\hline \multirow{3}{*}{ Parametr } & \multicolumn{8}{|c|}{ Stellaria media extract [\%] } \\
\hline & \multicolumn{2}{|c|}{ Control } & \multicolumn{2}{|c|}{5} & \multicolumn{2}{|c|}{10} & \multicolumn{2}{|c|}{15} \\
\hline & A & B & A & B & A & B & A & B \\
\hline Fresh mass [g] & $\begin{array}{c}0.2944 \mathrm{~b} \\
\pm 0.06\end{array}$ & $\begin{array}{c}0.2534 \mathrm{~b} \\
\pm 0.06\end{array}$ & $\begin{array}{c}0.4880 \mathrm{a} \\
\pm 0.11\end{array}$ & $\begin{array}{c}0.4142 \mathrm{a} \\
\pm 0.11\end{array}$ & $\begin{array}{l}0.2187 \mathrm{~b} \\
\pm 0.06\end{array}$ & $\begin{array}{c}0.5435 \mathrm{a} \\
\pm 0.15\end{array}$ & $\begin{array}{c}0.2007 \mathrm{~b} \\
\pm 0.04\end{array}$ & $\begin{array}{c}0.2229 \mathrm{~b} \\
\pm 0.03\end{array}$ \\
\hline Dry mass [g] & $\begin{array}{c}0.1877 \mathrm{bc} \\
\pm 0.04\end{array}$ & $\begin{array}{c}0.1393 \mathrm{a} \\
\pm 0.04\end{array}$ & $\begin{array}{c}0.2041 \mathrm{a} \\
\pm 0.08\end{array}$ & $\begin{array}{c}0.1479 \mathrm{a} \\
\pm 0.04\end{array}$ & $\begin{array}{c}0.1316 \mathrm{c} \\
\pm 0.03\end{array}$ & $\begin{array}{l}0.1600 \mathrm{a} \\
\pm 0.05\end{array}$ & $\begin{array}{c}0.1641 \mathrm{bc} \\
\pm 0.03\end{array}$ & $\begin{array}{c}0.1494 \mathrm{a} \\
\pm 0.04\end{array}$ \\
\hline $\begin{array}{l}\text { Water content } \\
{[\%]}\end{array}$ & $\begin{array}{c}35.37 \mathrm{~b} \\
\pm 0.04\end{array}$ & $\begin{array}{c}44.56 \mathrm{c} \\
\pm 0.04\end{array}$ & $\begin{array}{c}59.09 \mathrm{a} \\
\pm 0.08\end{array}$ & $\begin{array}{c}63.68 \mathrm{~b} \\
\pm 0.04\end{array}$ & $\begin{array}{c}38.75 \mathrm{~b} \\
\pm 0.03\end{array}$ & $\begin{array}{l}70.49 \mathrm{a} \\
\pm 0.05\end{array}$ & $\begin{array}{l}18.25 \mathrm{c} \\
\pm 0.03\end{array}$ & $\begin{array}{c}33.30 \mathrm{~cd} \\
\pm 0.04\end{array}$ \\
\hline
\end{tabular}

mean values \pm SD marked with letters $a, b, c$ differ significantly according to Duncan's test $p \leq 0.05$

Discussion

Modern agriculture pays great attention to the skilful and environmentally safe increase in the quantity and quality of crops (Górecki et al., 1994). The first important stage in obtaining high-quality crop plants is to provide them with the right conditions for seed germination. Changes occurring during germination are regulated at the molecular, cellular and whole seeds levels (Grzesiuk, Kulka, 1981; Higashiyama et al., 2003). In the first stage of germination an important role is played by the seed coat (Herse, 1982). Seed coat accounts for 12 to $20 \%$ of the mass of seeds, and the remaining seed components of the embryo are: cotyledon and germinal root, which constitute respectively 75 to $83 \%$ and $5 \%$ of the mass (Byszewski, 1972). The chemical composition of the seed coat and embryo is different, depending on the physiological functions performed, and the stage of seed development (Grzesiuk, Kulka, 1981; Niewiadomski, 1990).

The differences in germination process and early stages of Phaseolus vulgaris growth observed during the experiment showed the allelopathic properties of Stellaria media, as well as the protective effect of the seed coat in the interaction of seeds with allelopathic substances. Previous studies on allelopathic properties of 
chickweed show that the presence of this weed causes a decrease of Brassica napus L. var. napus crops (Lutman et al., 2000), reduced production of Triticum aestivum L. grains (Lutman, 2002), and also depending on the concentration of the extract favourably or adversely effects on the germination and growth of different cultivars of Zea mays L. (Zandi et al., 2019). However, S. media does not affect every plant in the same negative way. This thesis was confirmed by this experiment (Fig. 1-8; Tab. 2-3).

Seed germination is a complex process that includes both catabolic and anabolic reactions and biochemical transformations (Grzesiuk, Kulka, 1981). The seed viability index accepted on an international scale is germination capacity (Dąbrowska, 1998). In this study it was observed that the percentage values of germinated $P$. vulgaris seeds with and without seed coat were the largest for seeds watered with $5 \%$ aqueous extracts from S. media dry shoots, compared to seeds germinated on distilled water (Fig. $1-2)$. In addition, a high number of germinated seeds was observed on $10 \%$ extracts in the group of bean seeds with seed coat. The opposite effect was for seeds without seed coat, where $10 \%$ extracts completely inhibited the germination of bean seeds (Fig. 2).

Seed germination studies that take place in laboratory conditions do not exactly reflect crop conditions (Faligowska et al., 2012). Therefore, the vigour of seeds to additionally assess is proposed (Conreras, Barros, 2005). In this experiment, the seed emergence (SE) index values for both tested samples (seeds with and without coat) were characterised by a various seed reaction to aqueous extracts from $S$. media shoots (Fig. 3-4). In the case of seed with seed coat, the relationship between SE index and the value of the aqueous concentration of $S$. media can be noticed. Compared to the SE from the control, it was observed that the higher concentration of the extract, the faster the SE index values decreased. Compared to the control, in the case of seeds without coat, only $5 \%$ extract of chickweed caused an increase in the SE index.

Significantly higher values of seed vigour index (SVI) for bean seeds with seed coat were noted. In contrast, seeds without seed coat were more sensitive to aqueous extracts from S. media (Fig. 5-6). Probably, these results were connected with the presence or absence of seed coat. The seed coat has a protective function of the seed against harmful external factors, including: bacterial and fungal infections, as well as drying out, the influence of toxic chemical compounds and mechanical damage (Grzesiuk, Kulka, 1981; Możdżeń, Rzepka, 2016).

Biometric analysis showed the stimulating effect of 5 and $10 \%$ aqueous extracts on the growth of 7-day-old P. vulgaris seedlings, germinated with seed coat. For seeds without seed coat, quite the opposite results were obtained (Fig. 7-8). Both, in one and the second experimantal group of seeds in the presence of $15 \%$ of extracts from $S$. media, a total inhibition of seedlings growth was found (Tab. 2). The results obtained are consistent with the literature data of many authors. For example: Możdżeń et al. 
(2016) showed the inhibitory effect of aqueous extracts from Capsella bursa-pastoris (L.) Medik. on germination and growth of Lactuca sativa L. cv 'Maryna', Puła et al. (2016) studied the effect of aqueous extracts of Galium aparine L. on various cultivars of Zea mays L., Możdżeń et al. (2018) observed the allelopathic activity of Galinsoga parviflora Cav. and Oxalis fontana Bunge on early growth stages of different cultivars of Raphanus sativus L. var. radicula Pers, Zandi et al. (2018) confirmed the allelopathic properties of $S$. media on $R$. sativus var. radicula and others.

The increase in fresh and dry mass of bean seedlings, grown from seed with seed coat, was significantly the largest on substrates with $5 \%$ extracts, compared to the control (Tab. 3). At 10 and 15\% extract concentrations, the mass values were near to the control. The values of fresh mass in seedlings grown from seeds without seed coat were clearly higher in the case of extracts 5 and $10 \%$, in relation to the control. In the case of dry mass, no statistically significant changes were found in the values of this parameter. It can be supposed that the differences in mass increase are due to the disruption by the $S$. media extracts of the capture, transport and use of ions of calcium $\left(\mathrm{Ca}^{2+}\right)$, magnesium $\left(\mathrm{Mg}^{2+}\right)$, potassium $\left(\mathrm{K}^{+}\right)$and water (Das et al., 1997). According to Bieżanowska-Kopeć and Pisulewski (2006), bean seeds have antioxidant properties due to the polyphenols content, which are part of the plant's natural protective ingredients against harmful compounds. Another protective barrier for seeds with a seed coat may be cuticle, which, depending on the thickness and saturation with waxes, is an impermeable barrier to water and gases (Russi et al., 1992; Zeng et al., 2005). The chemical composition of seeds, their size and variety play an important role in mass growth and seed swelling (Rice, 1984).

The percentage of water content increased significantly in seeds without a seed coat - from 44.56 to $63.68 \%$ for seeds watered with a $5 \%$ extract, up to $70.49 \%$ for seeds grown on a $10 \%$ extract (Tab. 3). For seeds with seed coat grown in the presence of $5 \%$ extract, the percentage increase in water was smaller and amounted to $59.09 \%$. Seed coat protected the seeds against the negative allelopathic effects of the aqueous extract from S. media - inhibition of germination was observed only at a concentration of $15 \%$. It also did not allow for high absorption of the aqueous extract, as evidenced by the lower percentage of water in seeds with seed coat. The differences obtained most likely result from the presence in the extracts of chemical compounds that modify the properties of cell membranes and contribute to a low degree of water absorption, thereby reducing the germination rate of seeds (Siwek, 2008). Rut et al. (2012) report that allelopathic compounds inhibit roots hair formation, reducing their active surface, and thus reduce water uptake.

The essence of the allelopathy process is the secretion by the plants (donors) of specific chemical compounds that favourably or adversely affect other plants (acceptors) (Wójcik-Wojtkowiak, Politycka, 1998). Allelopathic reactions of one plant to anoth- 
er are the result of interactions of mixtures of different compounds, not just a single substance (Blum, 1996; Veronneau et al., 1997). In crops, the antagonistic effects of various groups of chemical compounds are more pronounced at low concentrations, compared to the action of individual substances. Herb of $S$. media contains oligosaccharides, saponins, flavonoids, proteins, provitamins, vitamins B1, B2, C, E, PP, triterpene glycosides, sugar alcohols and mineral salts (Vanhaecke et al., 2006; Hu et al., 2009), which can cause this kind of complex action. The analysed indexes show clearly that water extracts from dry S. media shoots show allelopathic properties for germination and early stages of bean growth. While, seed coat plays an important role in protecting seeds from the effects of aqueous extracts of chickweed. Experiment carried out here confirmed, that seeds throughout the entire life cycle of plants, despite the best protection against various stress factors, during germination become sensitive to any type of stress (Weiqiang et al., 2005).

\section{Conclusion}

(1) Germination indexes for seeds of Phaseolus vulgaris showed that seeds without seed coats were more sensitive to aqueous extracts from Stellaria media at low allelopathic compounds concentrations the seeds germinated similarly to distilled water, however at higher concentrations of this substances the process of germination was inhibited.

(2) The increase in the length of seedlings grown from seeds with coats and without them decreased with increasing allelopathic substances concentrations; in the presence of $15 \%$ of $S$. media extracts, inhibition of seedling growth was observed.

(3) The values of fresh and dry mass and the percentage of water content differed for each of the examined group of seeds, depending on the concentration of the extract used.

The author declares no conflict of interest related to this article.

\section{Conflict of interest}

\section{References}

Bieżanowska-Kopeć, R., Pisulewski, P.M. (2006). Wpływ procesów termicznych i biologicznych na pojemność przeciwutleniającą nasion fasoli (Phaseolus vulgaris L.). Żywność, 3(48), 51-64. [In Polish]

Blum, U. (1996). Allelopathic interactions involving phenolic acids. Journal of Nematology, 28, 259-267. Byszewski, W. (1972). Surowce roślinne. Warszawa: Wydawnictwo PWN. [In Polish]

Contreras, S., Barros, M. (2005). Vigor tests on lettuce seeds and their correlation with emergence. Ciencia e Investigacion Agraria, 32(1), 3-10. DOI: 10.7764/rcia.v32i1.301

Das, P., Samantaray, S., Rout, G.R. (1997). Studies on cadmium toxicity in plants, a review. Environmental Pollution, 98(1), 29-36. DOI: 10.1016/S0269-7491(97)00110-3

Dąbrowska, B. (1998). Wigor - istotne kryterium jakości nasion. Ogrodnictwo, 4(98), 10-13. [In Polish] 
Faligowska, A., Bartos-Spychała, M., Panasiewicz, K. (2012). Wpływ okresu przechowywania na wartość siewną i wigor zaprawionych nasion łubinu wąskolistnego. Progress in Plant Protection, 52(4), 1151-1155. [In Polish]

Gniazdowska, A., Oracz, K., Bogatek, R. (2004). Allelopatia - nowe interpretacje oddziaływań pomiędzy roślinami. Kosmos - Problemy Nauk Biologicznych, 53(2), 207-217. [In Polish]

Górecki, R.J., Grzesiuk, S. (1994). Światowe tendencje i kierunki uszlachetniania materiałów nasiennych. In: Uszlachetnianie materiałów nasiennych. Olsztyn-Kortowo, 9-24. [In Polish]

Grzesiuk, S., Kulka, K. (1981). Fizjologia i biochemia nasion. Warszawa: Wydawnictwo PWN. [In Polish] Herse, J. (1982). Szczegółowa uprawa roślin. Warszawa: Wydawnictwo PWN. [In Polish]

Hu, Y.M., Wang, H., Ye, W.C., Qain, I. (2009). New triterpenoid from Stellaria media (L.). Natural Product Research and Developmen, 23(14), 1274-1278. DOI: 10.1080/14786410701642532

Islam, A.K.M.M., Kato-Noguchi, H. (2012). Allelopathic potentiality of medicinal plant Leucas aspera. International Journal of Agricultural Sustainability, 4, 1-7.

Kunachowicz, H., Przygoda, B., Nadolna, I., Iwanow, K. (2017). Tabele składu i wartości odżywczej żywności. Warszawa: Wydawnictwo Lekarskie PZWL. [In Polish]

Lutman, P.J.W. (2002). Estimation of seed production by Stellaria media, Sinapis arvensis and Tripleurospermum inodorum in arable crops. Weed Research, 42, 359-369. DOI: 10.1046/j.1365-3180.2002.00296.x

Lutman, P.J.W., Bowerman, P., Palmer, G.M. (2000). Prediction of competition between oilseed rape and Stellaria media. Weed Research, 40, 255-269. DOI: 10.1046/j.1365-3180.2000.00182.x

Matuszkiewicz, W. (2006). Przewodnik do oznaczania zbiorowisk roślinnych Polski. Warszawa: Wydawnictwo PWN. [In Polish]

Molisch, H. (1937). Der Einfluss einer Pflanze auf die andere. Allelopathie. Verlang von Gustav Tischer. [In German]

Możdżeń, K., Barabasz-Krasny, B., Sołtys-Lelek, A., Stachurska-Swakoń, A., Puła, J. (2016). Wpływ wodnych ekstraktów z tasznika pospolitego (Capsella bursa-pastoris (L.) Medik.) na kiełkowanie i rozwój sałaty siewnej odmiany 'Maryna' (Lactuca sativa L. cv 'Maryna'). Agronomy Science, 71(2), 1-10. [In Polish]

Możdżeń, K., Barabasz-Krasny, B., Zandi, P., Turisova, I. (2018). Influence of allelopathic activity of $G a-$ linsoga parviflora Cav. and Oxalis fontana Bunge on the early growth stages of cultivars Raphanus sativus L. var. radicula Pers. Biologia, 73, 1187. DOI: 10.2478/s11756-018-0144-0

Niewiadomski, H. (1990). Rapeseed. Chemistry and Technology. Amsterdam: Elsevier.

Nowiński, M. (1961). Obecny stan badań nad allelopatią. Postępy Nauk Rolniczych, 3(69), 39-57. [In Polish]

Oleszek, W. (1992). Techniki badań allelopatii. Wiadomości Botaniczne, 36, 17-25. [In Polish]

Oleszek, W. (1996). Allelopatia - rys historyczny, definicja, nazewnictwo. In: Teoretyczne i praktyczne aspekty allelopatii. Materiały Konferencyjne IUNG, Puławy K(10), 5-15. [In Polish]

Parus, A. (2015). Gwiazdnica pospolita (Stellaria media Vill.) - właściwości biologiczne i lecznicze. Postępy Fitoterapii, 3, 153-156. [In Polish]

Puła, J., Barabasz-Krasny, B., Możdżeń, K., Sołtys-Lelek, A., Leparczyk, A. (2016). Effect of aqueous extracts of Sticky willy (Galium aparine L.) on the growth of seedlings of selected maize varieties (Zea mays L.). Notulae Botanicae Horti Agrobotanici Cluj-Napoca, 4(2), 518-524. DOI: 10.15835/ nbha442104750

Rice, E.L. (1984). Allelopathy, 2nd ed. New York: Academic Press.

Russi, L., Cocks, P.S., Roberts, E.H. (1992). Coat thickness and hard-seedness in some Medicago and Trifolium species. Seed Science and Technology, 2, 239-249. 
Rut, G., Rzepka, A., Stokłosa-Wojtaś, A., Migdałek, G. (2012). Wpływ substancji allelopatycznych na kiełkowanie nasion, wzrost i rozwój roślin. Annales Universitatis Paedagogicae Cracoviensis Studia ad Didacticam Biologiae Pertinentia II, 78-87. [In Polish]

Siwek, M. (2008). Rośliny w skażonym metalami ciężkimi środowisku poprzemysłowym. Część II. Mechanizmy detoksykacji i strategie przystosowania roślin do wysokich stężeń metali ciężkich. Wiadomości Botaniczne, 52(3/4), 7-23. [In Polish]

van der Vegte, F.W. (1978). Population differentiation and germination ecology in Stellaria media (L.) Vill. Oecologia, 37, 231-245.

Vanhaecke, M., Ende, W.V.D., Van Laere, A., Herdewijn, P., Lescrinier, E. (2006). Complete NMR characterization of lychnose from Stellaria media (L.) Vill. Carbohydrate Research, 341, 2744-2750. DOI: 10.1016/j.carres.2006.09.001

Veronneau, H., Greer, A.F., Daigle, S., Vincent, G. (1997). Use of mixtures of allelochemicals to compare bioassays using red maple, pin cherry, and American elm. Journal of Chemical Ecology, 23, 11011117. DOI: 10.1023/B:JOEC.0000006389.50186.e3

Weiqiang, L., Khan, M., Yamaguchi, S., Kamiya, Y. (2005). Effects of heavy metals on seed germination and early seedling growth of Arabidopsis thaliana. Journal of Plant Growth Regulation, 46, 45-50. DOI: $10.1007 /$ s10725-005-6324-2

Wójcik-Wojtkowiak, D., Politycka, B., Weyman-Kaczmarkowa, W. (1998). Allelopatia. Poznań: Wydawnictwo Akademii Rolniczej im. Augusta Cieszkowskiego w Poznaniu. [In Polish]

Zandi, P., Barabasz-Krasny, B., Stachurska-Swakoń, A., Puła, J., Możdżeń, K. (2018). Allelopathic effects of Stellaria media (L.) Vill. on germination and early stages of growth of Raphanus sativus var. radicula. Annales Universitatis Paedagogicae Cracoviensis Studia Naturae, 3, 90-99. DOI: $10.24917 / 25438832.3 .7$

Zandi, P., Możdżeń, K., Barabasz-Krasny, B., Puła, J., Stachurska-Swakoń, A., Wang, Y. (2019). The influence of aqueous extracts from Stellaria media L. on the growth of Zea mays L. cultivars. Notulae Botanicae Horti Agrobotanici Cluj-Napoca, 47(3), 921-928. DOI: 10.15835/nbha47311597

Zeng, L.W., Cocks, P.S., Kailis, S.G., Kuo, J. (2005). Structure of the seed coat and its relationship to seed softening in Mediterranean annual legumes. Seed Science and Technology, 33, 351-362.

\section{Abstract}

The aim of the study was to determine the role of the seed coat in the presence of aqueous extracts from Stellaria media (L.) Vill. on germination and early growth stages of bean seeds Phaseolus vulgaris L. Dry shoots of the chickweed aqueous extracts were prepared, with which the bean seeds with coat and without coat were treated. The control group was seeds watered only with distilled water. After 7 days of the experiment, seed germination parameters, seed germination rate (SE), seed vitality index (SVI), seedling growth inhibition index (IP), fresh and dry mass values and percentage water content were determined. The experiment showed the germination capacity of bean seeds was varied, in relation to seeds from the control. With increasing concentrations of extracts, a significant reduction in the seed germination rate was observed, both for those with seed coat and without seed coat. The seed vitality index increased only in seeds with coat, and decreased in each of the applied concentrations of extracts in seeds without seed coat. The seedling growth inhibition index reached negative values in both groups of seeds tested only at a concentration of $5 \%$. In comparison to the control, IP was positive for seedlings watered with $15 \%$ extracts. For $P$. vulgaris seedlings grown on $5 \%$ of extracts the highest increase in the fresh mass was observed, in relation to the value of control mass. For seedlings grown from seeds with seed coat the differences in the dry mass values primarily were noted. The percentage of water content in bean seedlings varied depending on the group of seeds studied and the concentration of allelopathic substances in the chickweed aqueous extracts. The examined indexes of seed germination and seedling growth showed that in the case of $P$. vulgaris seeds without seed coat 
were more sensitive to aqueous extracts from dry shoots of $S$. media. Compared to the control group, in low concentrations of allelopathic substances the seeds germinated similarly to the distilled water, and at higher concentrations, the seeds germination, the seedlings growth and fresh and dry mass values were inhibited.

Key words: allelopathy, seed coat, fresh and dry mass, germination indexes

Received: [2019.08.05]

Accepted: [2019.11.20]

\section{Rola łupiny nasiennej w kiełkowaniu i wczesnych stadiach wzrostu fasoli (Phaseolus vulgaris L.), w obecności gwiazdnicy pospolitej (Stellaria media (L.) Vill.)}

Streszczenie

Celem badań było określenie roli łupiny nasiennej w obecności wodnych ekstraktów z Stellaria media (L.) Vill. na kiełkowanie i wczesne etapy wzrostu nasion fasoli żółtostrąkowej (Phaseolus vulgaris L.). Przygotowano wodne ekstrakty z suchych pędów gwiazdnicy pospolitej, którymi podlewano nasiona fasoli z łupiną nasienną i bez łupiny nasiennej. Grupę kontrolną stanowiły nasiona podlewane wyłącznie wodą destylowaną. Po upływie 7 dni eksperymentu wyznaczono parametry zdolności kiełkowania nasion, szybkość kiełkowania nasion (SE), wskaźnik żywotności nasion (SVI), wskaźnik hamowania wzrostu siewek (IP), a także określono przyrost świeżej i suchej masy oraz procentową zawartość wody. Eksperyment wykazał zróżnicowaną zdolność kiełkowania nasion fasoli, w stosunku do nasion z próby kontrolnej. Wraz ze wzrostem stężeń ekstraktów obserwowano wyraźne zmniejszenie wartości wskaźnika szybkości kiełkowania nasion, zarówno tych z łupiną nasienną, jak i bez łupiny nasiennej. Wskaźnik żywotności nasion wzrastał jedynie $\mathrm{u}$ nasion $\mathrm{z}$ łupiną nasienną, a malał $\mathrm{w}$ każdym $\mathrm{z}$ zastosowanych stężeń wyciągów $\mathrm{u}$ nasion pozbawionych łupiny nasiennej. Wskaźnik hamowania wzrostu siewek osiągał wartości ujemne w obu grupach nasion jedynie przy stężeniu 5\%. W porównaniu z kontrolą, IP był dodatni w przypadku siewek podlewanych 15\% ekstraktami. Największy przyrost świeżej masy, w stosunku do wartości mas z kontroli, zauważono u siewek $P$. vulgaris wyrosłych na podłożach z 5\% wyciągami. Różnice w przyroście suchej masy odnotowano dla siewek wyrosłych $\mathrm{z}$ nasion $\mathrm{z}$ łupiną nasienną. Procentowa zawartość wody w siewkach fasoli zmieniała się w zależności od grupy nasion oraz koncentracji związków allelopatycznych w wodnych wyciągach z gwiazdnicy. Analizowane wskaźniki kiełkowania nasion i wzrostu siewek wykazały, iż w przypadku $P$. vulgaris bardziej wrażliwe na wodne wyciągi z suchych pędów $S$. media były nasiona pozbawione łupiny nasiennej. W niskich stężeniach allelopatin nasiona kiełkowały podobnie jak na wodzie destylowanej, a w wyższych, kiełkowanie, przyrost na długość oraz wartości mas były wyraźnie hamowane.

Słowa kluczowe: allelopatia, łupina nasienna, świeża i sucha masa, wskaźniki kiełkowania

\section{Information on the author}

\section{Aleksandra Mazur}

She is interested in an allelopathic interaction between aqueous extracts from weeds and different seeds during germination and growth. 